\title{
Outcomes of heart transplantation in children with hypoplastic left heart syndrome previously palliated with the Norwood procedure
}

\author{
Bahaaldin Alsoufi, MD, ${ }^{\mathrm{a}}$ William T. Mahle, MD, ${ }^{\mathrm{b}}$ Cedric Manlhiot, BSc, ${ }^{\mathrm{c}}$ Shriprasad Deshpande, MD, \\ Brian Kogon, MD, ${ }^{a}$ Brian W. McCrindle, MD, MPh, ${ }^{\mathrm{c}}$ and Kirk Kanter, $\mathrm{MD}^{\mathrm{a}}$
}

\begin{abstract}
Background: Following the Norwood operation, unfavorable hemodynamic or anatomic factors might disqualify children from progressing through subsequent palliative surgeries necessitating listing for heart transplantation. Those patients often have immune, clinical, or anatomic risk factors that could preclude donor allocation, increase operative risk, and diminish late survival. We studied transplantation outcomes in those patients using the Pediatric Heart Transplant Study database.
\end{abstract}

Methods: A total of 253 children who had prior Norwood were listed for transplantation (1993-2012). Competing risks analysis modeled events after listing (death, transplantation) and after transplantation (death, retransplantation) and examined factors affecting outcomes.

Results: Patients were listed following Norwood $(n=89,35 \%)$, Glenn $(n=96$, $38 \%)$, and Fontan $(\mathrm{n}=68,27 \%)$. Competing risk analysis showed that 1 year after listing, $23 \%$ of patients had died, $70 \%$ had received transplantation, and $7 \%$ were alive without transplantation. Factors associated with death without transplantation included UNOS status I (HR 3.44 [1.58-7.49], $P=.002$ ) and mechanical circulatory support (HR 4.13 [2.04-8.34], $P<.001$ ). Overall, 188 patients received transplantation. Competing risk analysis showed that 10 years following transplantation, $40 \%$ had died, $7 \%$ had received retransplantation, and $53 \%$ were alive without retransplantation. Factors associated with death following transplantation were race other than white (HR 2.18 [1.19-3.99], $P=.01$ ), and donor mode of death other than anoxic brain injury (HR 2.23 [1.00-5.01], $P=.05)$.

Conclusions: Heart transplantation can salvage children failing palliation following Norwood with outcomes comparable to those reported for other congenital cardiac anomalies. Efforts to stabilize patients and increase donor pool could improve survival by decreasing the high waiting list mortality. In patients who received transplantation, survival is not affected by last palliation stage or sensitization, reflecting current advances in perioperative management and immunosuppression management strategies. (J Thorac Cardiovasc Surg 2016;151:167-75)

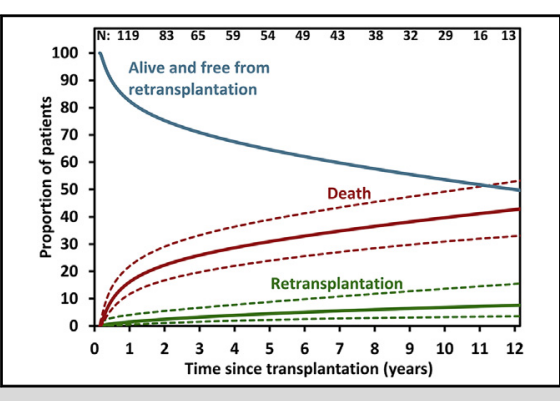

Prevalence of events (death, retransplantation) following heart transplantation.

\section{Central Message}

Listing for heart transplantation after Norwood is associated with high listing mortality and acceptable survival after transplantation.

\section{Perspective}

Heart transplantation can salvage children failing palliation following Norwood with outcomes comparable to those reported for other congenital cardiac anomalies. Nonetheless, waiting list mortality is high and efforts to stabilize those patients and increase donor pool could improve survival by decreasing the high waiting list mortality.

See Editorial Commentary page 176.

See Editorial page 1404 in the December issue.

\footnotetext{
From the a Division of Cardiothoracic Surgery, Children's Healthcare of Atlanta, Emory University School of Medicine, Atlanta, Ga; ' Division of Cardiology, Department of Pediatrics, Children's Healthcare of Atlanta, Emory University School of Medicine, Atlanta, Ga; and ${ }^{\mathrm{c} L a b a t t}$ Family Heart Center, Hospital for Sick Children, the University of Toronto, Toronto, Ontario, Canada.

Read at the 95th Annual Meeting of The American Association for Thoracic Surgery, Seattle, Washington, April 25-29, 2015.

Received for publication April 29, 2015; revisions received Sept 1, 2015; accepted for publication Sept 12, 2015; available ahead of print Oct 29, 2015.

Address for reprints: Bahaaldin Alsoufi, MD, Division of Cardiothoracic Surgery, Emory University School of Medicine, Children's Healthcare of Atlanta, 1405 Clifton Road, NE, Atlanta, GA 30322 (E-mail: balsoufi@hotmail.com). $0022-5223 / \$ 36.00$

Copyright (c) 2016 by The American Association for Thoracic Surgery http://dx.doi.org/10.1016/j.jtcvs.2015.09.081
}

丹 Supplemental material is available online.

The prognosis of children born with single ventricle malformations associated with systemic obstruction such as hypoplastic left heart syndrome (HLHS) and related anomalies have improved with the introduction of multistage palliation starting with the Norwood operation. ${ }^{1,2}$ Several refinements in surgical and perfusion techniques, along with advances in perioperative care, percutaneous 


\section{Abbreviations and Acronyms \\ $\mathrm{CI}=$ confidence interval \\ $\mathrm{ECMO}=$ extracorporeal membrane oxygenation \\ HLHS = hypoplastic left heart syndrome \\ HR = hazard ratio \\ IQR = interquartile range \\ PHTS $=$ Pediatric Heart Transplant Study \\ PRA $=$ panel reactive antibodies \\ UNOS $=$ United Network for Organ Sharing}

intervention, and outpatient management have all contributed to superior outcomes of those patients in the current era. ${ }^{1,2}$ Nonetheless, the success of this multistage palliation strategy depends on the presence of wellidentified anatomic and hemodynamic criteria. The presence of unfavorable anatomic or hemodynamic factors might disqualify those patients from progressing through subsequent palliative stages or might cause late deterioration following completion of all palliative stages (ie, the Fontan operation); all necessitating listing to receive heart transplantation. $^{3-10}$

Those patients often have a number of clinical, anatomic, and immune risk factors that could preclude donor heart allocation, increase operative risk, or diminish late survival following transplantation. ${ }^{3-10}$ Few single-institution studies have shown good outcomes of heart transplantation to salvage patients failing the multistage palliation strategy following Norwood. ${ }^{4,6,9}$ On the other hand, some studies have shown that this group of patients was associated with the worst outcomes among children receiving heart transplantation for various other congenital and noncongenital etiologies. ${ }^{5,7}$ Analysis of outcomes and risk factors of heart transplantation in this patient population from single-institution studies have been limited by the small number of patients. The Pediatric Heart Transplant Study (PHTS) collects data from multiple transplant programs and provides a unique opportunity to examine outcomes in this patient population. In the current study, we describe results of all children with HLHS and related single-ventricle anomalies who were listed for heart transplantation at various stages of their multistage palliation following Norwood and examined factors that affected death before transplantation and outcomes following heart transplantation.

\section{PATIENTS AND METHODS \\ Inclusion Criteria}

The PHTS database is administered by the Data Collection and Analysis Center at the University of Alabama at Birmingham, with prospective data collection from patients at member institutions listed for heart transplantation aged younger than 18 years. Patients are tracked over time by the data collection center to ensure all of the appropriate follow-up and event forms are submitted each year. The data collection center reaches out to centers that do not submit follow-up forms for all of their patients each year. The PHTS database was queried to identify all patients with HLHS or related single-ventricle anomalies who had prior first stage palliation with the Norwood operation and were listed for heart transplantation at different stages following their initial palliation (Norwood, Glenn, or Fontan). Patients with HLHS and related single-ventricle anomalies who underwent primary heart transplantation without prior Norwood palliation (including those who had initial hybrid-type palliation) were excluded. We identified 253 patients who were listed for heart transplantation from all participating institutions during the study period of January 1, 1993, through December 31, 2012. Although there are currently 52 centers that participate in the PHTS database, there were 37 centers participating during our study interval, with 35 centers that submitted cases entered in our patient cohort. Approval from the institutional review board for each participating center was obtained before inclusion in the PHTS database.

\section{Statistical Analysis}

Data are described as means with standard deviations, medians with interquartile ranges (IQRs), or frequencies as appropriate. Variables and categories with low frequency are reported in the descriptive statistics but were collapsed (when possible) or excluded for further risk factor analyses. Variables with limited or no events in the patient population or variables considered not to be relevant for this particular analysis were also excluded. The association between risk factors and time-dependent outcomes (mortality before transplantation, mortality after heart transplantation, overall mortality after listing) was modeled in multiphase parametric hazard models (maximum likelihood estimates for parameter estimation) with competing risk analysis to determine proportion of patients in each of the outcomes over time. Risk factor analysis was first performed at the univariable level where all potential risk factors were assessed separately. To handle the problem of some missing data, we limited risk factor analyses to variables with a sufficient amount of data and we used mean imputation of missing data for multivariable models. Potential risk factors with a univariable $P<.10$ were then included in a multivariable regression model with backward selection of variables to obtain a final regression model. For the purpose of risk factor analyses, a unified phase of risk was used, as the number of events in each phase was too low to model separately. Bootstrap bagging resampling was used to validate our multivariable models (500 random resamples). All statistical analyses were performed using SAS v9.4 (SAS Inc, Cary, NC).

\section{RESULTS \\ Patient Characteristics}

During the study period, 253 children who had prior first stage palliation with the Norwood operation were listed for heart transplantation. There were 165 boys $(65 \%)$ and their races included white $(\mathrm{n}=197,78 \%)$, African American $(\mathrm{n}=27,11 \%)$, Hispanic $(\mathrm{n}=18,7 \%)$, Asian $(\mathrm{n}=3$, $1 \%)$, and mixed $(\mathrm{n}=8,3 \%)$. The underlying congenital heart disease was HLHS $(\mathrm{n}=228,90 \%)$ or other single-ventricle variants $(\mathrm{n}=25,10 \%)$. Patients were grouped according to their physiology at the time of listing; thus, patients who were unable to tolerate their Glenn physiology and were reverted back to Norwood physiology before listing were grouped with the Norwood cohort. Similarly, patients who were unable to tolerate their Fontan physiology and were reverted back to Glenn physiology before listing were grouped with the Glenn cohort. The physiology at time of listing was Norwood $(n=89,35 \%)$, 
Glenn $(\mathrm{n}=96,38 \%)$, or Fontan $(\mathrm{n}=68,27 \%)$. Median listing age was 1.5 years (IQR 0.4-4.2) and median weight was $9.5 \mathrm{~kg}$ (IQR 5.1-14.9). At time of listing, 32 patients $(13 \%)$ were on mechanical circulatory support (30 of those on extracorporeal membrane oxygenation [ECMO]) and 12 patients $(5 \%)$ had renal failure requiring renal replacement therapy. Twenty patients $(8 \%)$ had evidence of protein losing enteropathy. The listing status was United Network for Organ Sharing (UNOS) status I (IA and IB) in 188 patients $(74 \%)$ and II in 65 patients $(26 \%)$. The panel reactive antibodies (PRAs) were as follows: T-cell PRAs (class I) were available for 147 patients and were $\leq 10 \%$ $(\mathrm{n}=88,60 \%), 11 \%$ to $80 \%(\mathrm{n}=35,24 \%)$, or $\geq 80 \%$ $(\mathrm{n}=24,16 \%)$. B-cell PRAs (class II) were available for 142 patients and were $\leq 10 \%(\mathrm{n}=80,56 \%), 11 \%$ to $80 \%(\mathrm{n}=47,33 \%)$, or $\geq 80 \%(\mathrm{n}=15,11 \%)$.

A total of 112 patients (44\%) were listed in the early era of our series (1993-2002) and 141 (56\%) in the late era of our series (2003-2012). Evaluation of patients' characteristics between the 2 eras showed that the physiologic groups and the use of mechanical circulatory support were comparable, although the percentage of patients listed at UNOS status I was higher in the late era (Table E1).

Overall, 188 patients $(74 \%)$ received heart transplantation after a median waiting list duration of 37 days (IQR 13-87) in the early era and 65 days (IQR 26-155) in the late era $(P=.07)$. The median age at time of heart transplantation was 2.1 years (IQR 0.6-5.1) and median weight was $10.2 \mathrm{~kg}$ (IQR 6.0-16.2). At time of heart transplantation, 18 patients $(7 \%)$ had mechanical circulatory support (including ECMO in 16). Eighty (43\%) of those transplantations occurred in the early era of our series, and $108(57 \%)$ occurred in the late era of our series.

\section{Competing Risks Analysis of Events Following Listing for Transplantation}

Following listing for heart transplantation in those 253 patients, $188(74 \%)$ received heart transplantation, 58
$(23 \%)$ died before heart transplantation, and $7(3 \%)$ were delisted. The causes of death before transplantation are detailed in Table E2.

Survival following listing for heart transplantation is depicted in Figure 1. Competing risks analysis showed that at 1 month following listing, $8 \%$ of patients had died without transplantation, $26 \%$ had undergone heart transplantation, and $66 \%$ remained alive on the waiting list. At 6 months following listing, $21 \%$ of patients had died without transplantation, $59 \%$ had undergone heart transplantation, and $20 \%$ remained alive on the waiting list. At 1 year following listing, $23 \%$ of patients had died without transplantation, $70 \%$ had undergone heart transplantation, and 7\% remained alive on the waiting list (Figure 2).

Factors associated with death before transplantation were analyzed and are presented in Table E3. Early listing after Norwood, coupled with younger age and lower weight, was associated with higher mortality before transplantation on univariable analysis. However, on multivariable analysis, the factors associated with death before transplantation were mechanical circulatory support (HR 4.13 [2.04-8.34], $P<.001$ ) (Figure 3, A), UNOS status I (HR 3.44 [1.58-7.49], $P=.002$ ) (Figure $3, B$ ), and higher mean pulmonary artery pressure (HR 1.07 per $1 \mathrm{~mm} \mathrm{Hg}$ increase [1.03-1.10], $P<.001$ ) (Table E4).

\section{Competing Risks Analysis of Events Following Heart Transplantation}

Following heart transplantation in 188 patients, $8(4 \%)$ underwent retransplantation, $53(28 \%)$ died without retransplantation, and $127(68 \%)$ remained alive without retransplantation. The causes of death following heart transplantation are detailed in Table E2.

Competing risks analysis showed that at 1 year following heart transplantation, $2 \%$ of patients had undergone retransplantation, $17 \%$ had died without retransplantation, and $81 \%$ were alive without retransplantation. At 10 years
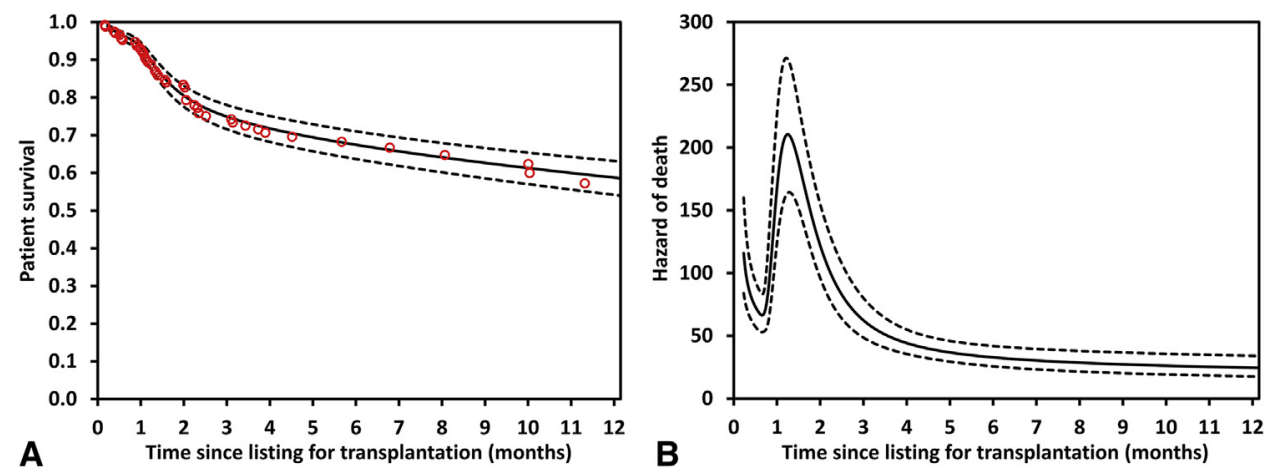

FIGURE 1. Time-dependent survival (A) and risk hazard of death (B) following listing for heart transplantation in 253 children who had prior first stage Norwood palliation. The solid lines in the parametric model represent parametric point estimates and the dashed lines enclose the $95 \%$ confidence interval. Circles represent nonparametric estimates. 


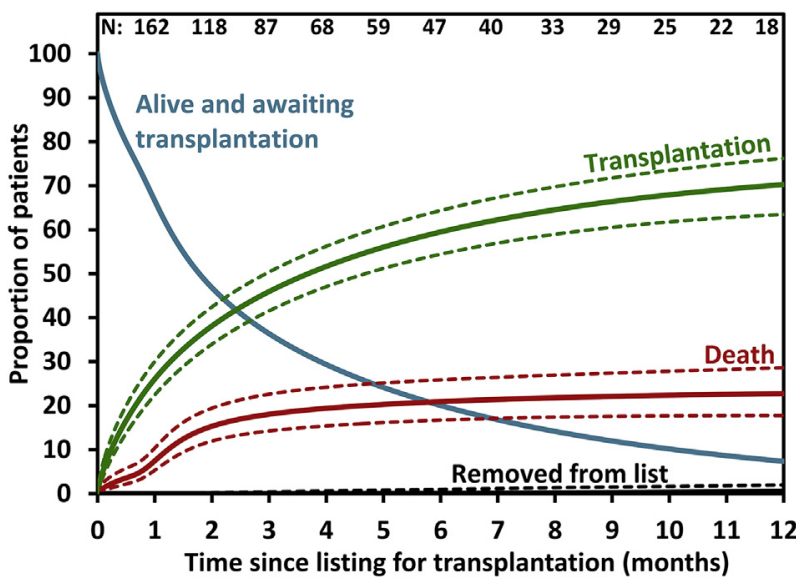

FIGURE 2. Competing risks depiction of events (death without transplantation, heart transplantation, with the remaining being alive on the waiting list) following listing for heart transplantation in 253 children who had prior first stage Norwood palliation. Competing risks analysis showed that the hazard for death before heart transplantation was characterized by the presence of an early hazard phase during the initial 2 months following listing and a persistent hazard of death that continued during the constant and late phases over the following 10 months. The hazard for heart transplantation was characterized by the presence of a high early phase during the initial 2 months following listing, followed by lower constant and late phases over the following 10 months.

following heart transplantation, $7 \%$ had undergone retransplantation, $40 \%$ had died without retransplantation, and $53 \%$ were alive without retransplantation (Figure 4).

Factors associated with death following transplantation were analyzed and are presented in Table E3. On multivariable analysis, the factors associated with death following transplantation were nonwhite race (HR 2.18 [1.19-3.99], $P=.01)$, and donor death other than anoxic brain injury (HR 2.23 [1.00-5.01], $P=.05$ ) (Table E5). Interestingly, survival following transplantation was not affected by the physiologic stage at time of transplantation, UNOS status, the presence of high PRAs, or the era (Figure 5, A-D).

Of importance, 13 patients $(7 \%)$ underwent ABOincompatible heart transplantation. Among those, 1 patient had acute rejection requiring early retransplantation and died due to sepsis and multiorgan failure, 1 patient died almost 5 months following transplantation from respiratory failure, and the remaining 11 patients were alive and free from retransplantation at a follow-up ranging from 0.2 to 2.6 years following heart transplantation.

Overall, 8 patients $(4 \%)$ underwent retransplantation. The causes for listing for retransplantation included allograft vasculopathy $(\mathrm{n}=3)$, nonspecific graft failure $(n=2)$, acute rejection $(n=1)$, and other $(n=2)$. Naturally, no risk factors were identified for retransplantation due to the small number of events. Of the 8 patients who received retransplantation, $3(38 \%)$ died and $5(62 \%)$ were alive without second retransplantation.

Overall survival following heart transplantation at 1, 5, and 10 years was $82 \%$ (95\% CI 79\%-85\%), 68\% (95\% CI 64\%-72\%) and 59\% (95\% CI 54\%-64\%), respectively. On the other hand, overall survival for the entire cohort following listing for transplantation at 1,5 , and 10 years was $66 \%(95 \%$ CI $63 \%-59 \%), 51 \%(95 \%$ CI $48 \%$ $55 \%$ ), and $44 \%$ (95\% CI $40 \%-48 \%$ ), respectively.

\section{Rejection Following Heart Transplantation}

Freedom from rejection following heart transplantation at 1 month, 3 months, 1 year, and 5 years was $75 \%$, $67 \%, 58 \%$, and $45 \%$, respectively (Figure 6). On multivariable analysis, risk factors associated with increased hazard of rejection included early era (HR 1.82 [1.12-2.95], $P=.02$ ), UNOS status I (HR 1.97 [1.14-3.39], $P=.01$ ), not listing after Norwood (HR 2.02 [1.18-3.44], $P=.01$ ), cold donor ischemic time (HR 1.17 per 60 minutes increase [1.00-1.38], $P=.05$ ), and positive prospective cross match (HR 2.18 [1.23-3.86], $P=.007$ ).

\section{DISCUSSION}

Despite improvements in early and late survival of children with HLHS and related single-ventricle anomalies undergoing the Norwood operation, a number of patients fail to progress through subsequent palliation stages and require listing
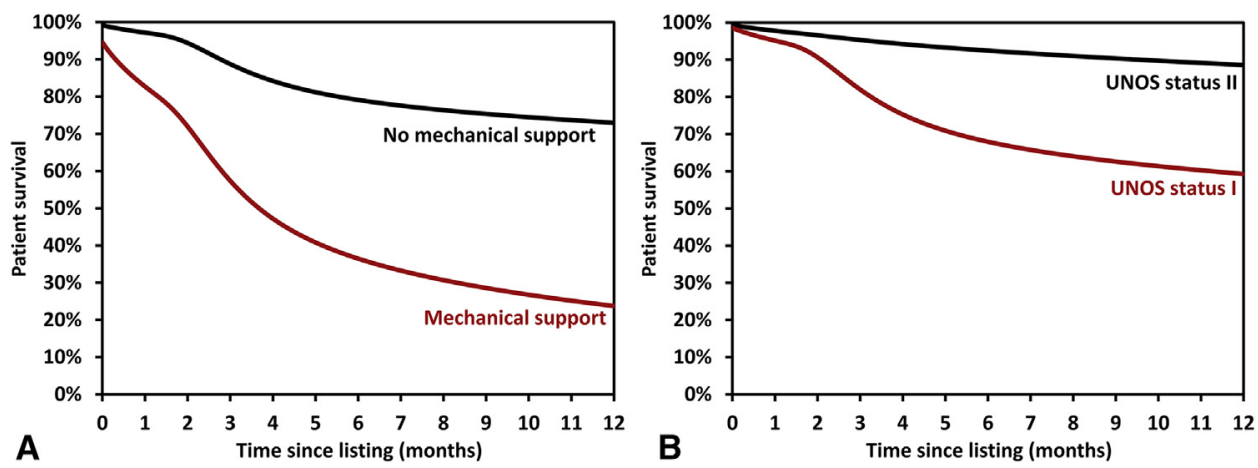

FIGURE 3. Parametric model for overall survival following listing for heart transplantation in children who had prior first stage Norwood palliation that is stratified by (A) requirement for mechanical circulatory support at time of listing, (B) United Network for Organ Sharing (UNOS) listing status. 


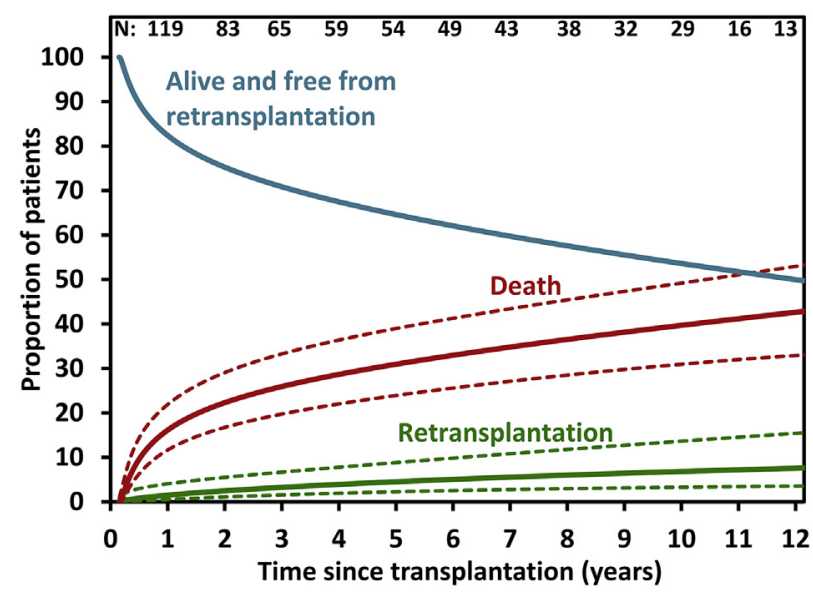

FIGURE 4. Competing risks depiction of events (death without retransplantation, heart retransplantation, with the remaining being alive without retransplantation) following heart transplantation in 188 children who had prior first stage Norwood palliation. Competing risks analysis showed that the hazard for death following heart transplantation was biphasic with the presence of both early and late phases of risk. This was characterized by the presence of a risk of mortality during the initial 1 year following surgery, a persistent low mortality with sustained and increasing attrition with time in later years after transplantation. The hazard for retransplantation was characterized by the presence of constant and late hazard phases of risk. Hazard of retransplantation was low for the first 1 to 2 years following heart transplantation and increased with time since transplantation.

for heart transplantation as a salvage procedure. ${ }^{3-10}$ Risk factors for this interstage failure include the development of dominant ventricular dysfunction and/or systemic atrioventricular valve regurgitation., ${ }^{3,10}$ Additionally, residual lesions, such as aortic arch obstruction, semilunar valve regurgitation, or pulmonary artery stenosis, can all have deleterious effects on a patient's physiology and hemodynamics. Although some of those residual lesions are amenable to surgical or percutaneous intervention, they are also associated with increased interstage failure and decreased transplant-free survival. ${ }^{11}$ In addition to interstage failure, a number of patients develop cardiac failure (myocardial dysfunction, arrhythmias) and/or systemic failure (protein losing enteropathy, plastic bronchitis, liver dysfunction, thromboembolism) following completion of the Fontan operation and require subsequent listing for heart transplantation. ${ }^{12-16}$ In the 2 largest single-institution reports of heart transplantation in children who had prior Norwood palliation, most patients were listed for transplantation following the Glenn procedure, although ventricular or systemic atrioventricular valve dysfunction were likely present early on after the Norwood operation. ${ }^{4,6}$ This is likely due to inclination to perform the Glenn operation that unloads the systemic ventricle, allows the opportunity to repair the atrioventricular valve, and provides a more stable modified in series circulation. ${ }^{1}$ Nonetheless, echocardiographic follow-up of those children showed that although the Glenn operation results in a decrease in indexed systemic ventricle volumes and mass, the ejection fraction of the systemic ventricle remains persistently low and the magnitude of atrioventricular valve regurgitation does not decrease. $^{17}$ Interestingly, the current review of the PHTS database showed a large proportion of patients received heart transplantation following the Norwood operation and before the Glenn operation, and that reflects variations in the approach to those difficult patients among different institutions.

In our current review, waiting list mortality was high, and $23 \%$ of those patients died before allocation of a proper donor heart. Previous reports have identified several groups of patients, such as infants, small-weight children, and sicker patients, such as those on ventilator, dialysis, or mechanical circulatory support, to be at higher risk of death before transplantation. ${ }^{18,19}$ Similarly, younger patients who were listed early after the Norwood operation in our series were at higher risk for dying without transplantation. This is likely due to the lack of heart donors that are suitable for this patient population. The use of ABO-incompatible heart transplantation to increase the donor pool in infants is an important development and is increasingly used in major pediatric heart transplantation centers with encouraging early results. $^{20,21}$ In our current series, ABO-incompatible heart transplantation was performed in 13 patients with outcomes that were comparable to those who did not receive ABO-incompatible heart transplantation; indicating a promising role in decreasing waiting time and consequently improving survival in those infants listed for transplantation. Similar also to the previous reports, risk factors for death after listing in our series included UNOS status I and the use of mechanical circulatory support. This obviously reflects the poor clinical condition of those patients awaiting heart transplantation and suggests an opportunity to improve survival by early listing and superior stabilization of those children before transplantation. Of note, when mechanical circulatory support was warranted, ECMO was the predominant (30/32) mode of mechanical circulatory support. This may explain the poor outcomes in those patients, as ECMO has historically been associated with poor waiting list and posttransplant survival that is inferior to that reported for other ventricular-assist devices. ${ }^{22-25}$ Although challenging, there is an increased experience in Europe and North America with ventricular-assist support in children with congenital heart disease and this strategy likely will play an additional role in the stabilization of infants with impending end-organ damage before heart transplantation. $^{26-29}$ Several recent reports have shown that outcomes of heart transplantation in children who were bridged with a ventricular assist device were comparable to those who did not need a ventricular-assist device. ${ }^{26-29}$ Although 

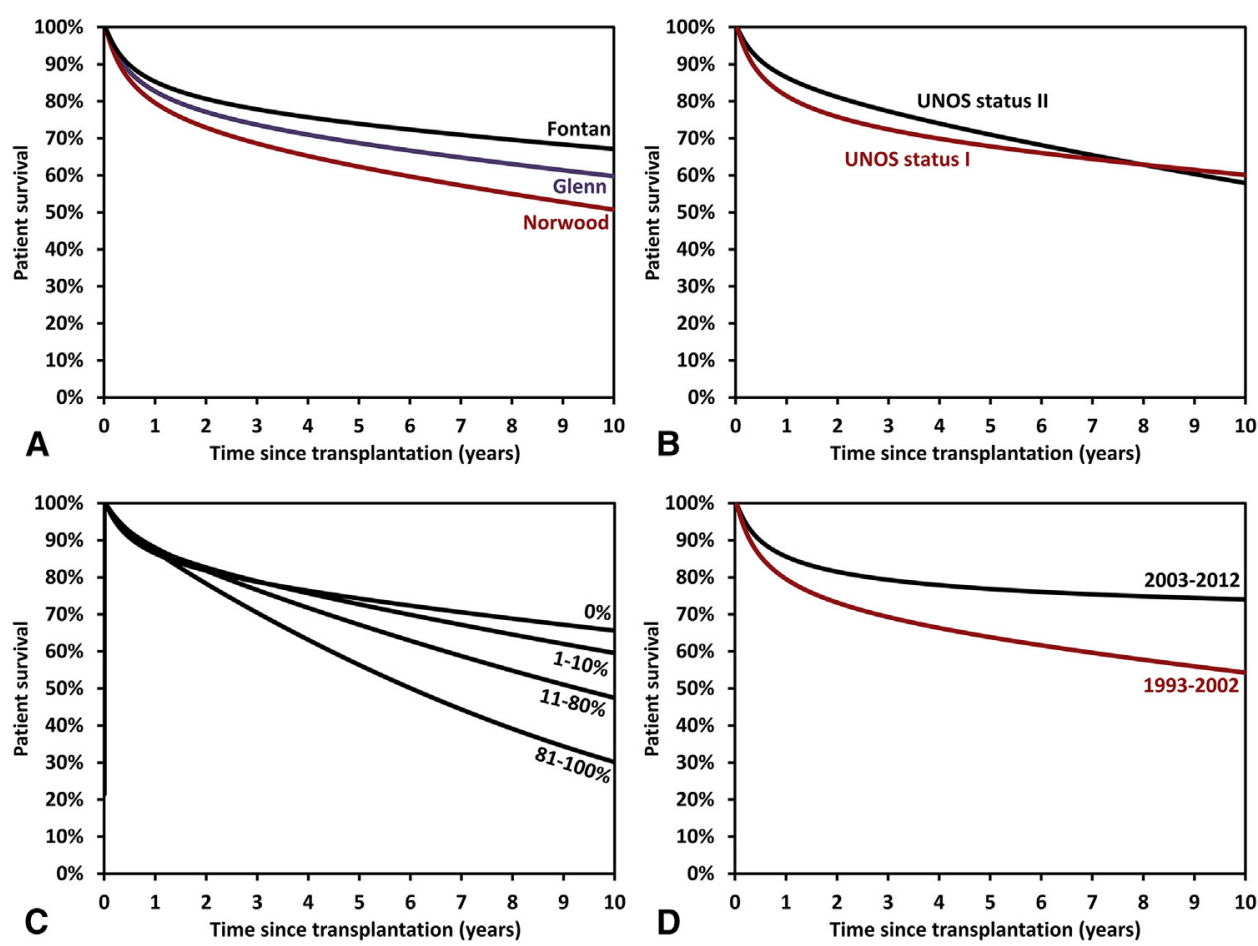

FIGURE 5. Parametric model for survival following heart transplantation in children who had prior first stage Norwood palliation that is stratified by (A) physiologic stage at time of transplantation (Norwood, Glenn, or Fontan); (B) United Network for Organ Sharing (UNOS) status at time of transplantation; (C) panel reactive antibodies (PRAs): 0\%, 1\%-10\%, 11\%-80\%, 80\%-100\%; (D) era at time of transplantation (1993-2002, 2003-2012).

most of the current experience is in children with cardiomyopathy, it is expected that the number of infants and children with single-ventricle who are bridged to heart transplantation with a ventricular-assist device will increase, and there have been a number of innovations in the implantation techniques of those devices to accommodate for the complex anatomy.

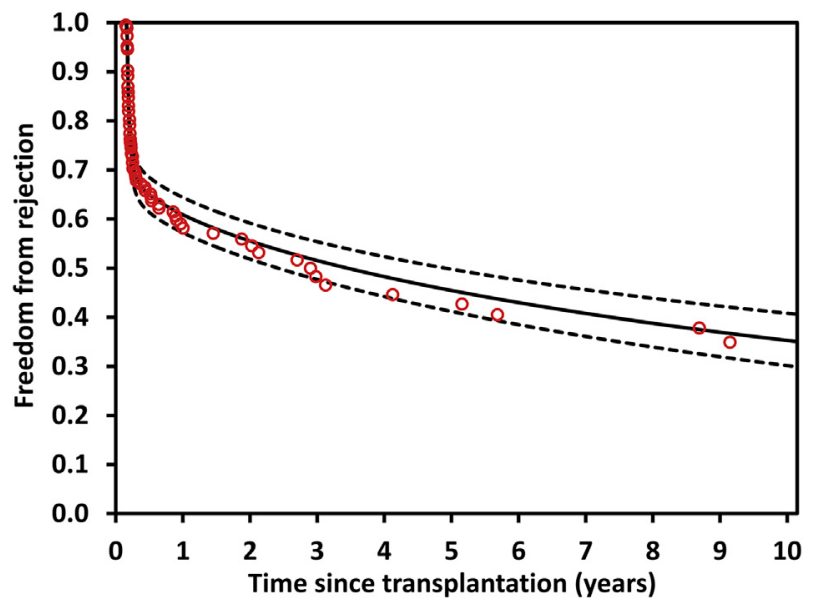

FIGURE 6. Parametric model for freedom from first rejection following heart transplantation in 188 children who had prior first stage Norwood palliation. The solid lines in the parametric model represent parametric point estimates and the dashed lines enclose the $95 \%$ confidence interval. Circles represent nonparametric estimates.
Several reports from large institutions and transplantation registries identified congenital heart disease as a risk factor for mortality after heart transplantation in children. ${ }^{5,12,19,30-32}$ Moreover, infants with previously palliated HLHS were shown to have the worst outcomes. ${ }^{5}$ A recent study from the PHTS showed that 1-year survival after heart transplantation in 739 infants 6 months old or younger was the lowest for infants with previously palliated HLHS $(70 \%)$ compared with $89 \%$ in those with cardiomyopathy, $82 \%$ in those with non-Norwood surgically corrected congenital heart disease, and $79 \%$ in those with nonpalliated HLHS. ${ }^{5}$ Those inferior outcomes in patients with palliated HLHS can be attributed to several factors, including increased allosensitization because of the multiple previous surgeries, blood transfusions, and the use of homograft tissue for arch reconstruction. This sensitization can be associated with increased waiting list duration, higher waiting list mortality, deteriorating condition before heart transplantation, emergence of organ dysfunction, and potentially higher incidence of rejection, all leading to increased operative risk, and poor graft and late patient survival. Additional problems include a more complicated surgery at time of heart transplantation due to multiple prior sternotomies and the frequent need for concomitant arch reconstruction or pulmonary artery augmentation, which can be associated with a more prolonged surgery and organ ischemia and consequently 
with inferior early and late outcomes. ${ }^{4-6,9}$ Nonetheless, recent reports from experienced institutions have suggested that heart transplantation can be used to salvage selected patients who failed multistage palliation following Norwood with results comparable to those in children with other forms of congenital heart disease. ${ }^{4,6} \mathrm{~A}$ recent review from Atlanta that examined a singleinstitution experience with heart transplantation in 124 children with congenital heart disease showed that 1-, 5-, and 10-year survival was $81 \%, 66 \%$, and $52 \%$, respectively, which is similar to survival in our current patient cohort $(82 \%, 68 \%$, and $59 \%$ at 1,5 , and 10 years, respectively). ${ }^{9}$

Despite that the risk of death before transplantation was the highest in infants listed for transplantation following Norwood before Glenn, survival following heart transplantation was not significantly affected by the physiologic palliation stage before transplantation. Although several reports have suggested that heart transplantation in children following the Fontan operation was associated with inferior outcomes, this was not the case in our series. ${ }^{12,13,15,16}$ Patients who had prior Fontan operation might have several factors that could complicate heart transplantation, such as allosensitization, pulmonary hypertension, challenging operation due to multiple prior sternotomies, complex venous anatomy, requirement of concomitant pulmonary artery reconstruction, lack of vascular access, and the presence of collaterals with subsequent risk of bleeding, in addition to poor clinical condition due to protein losing enteropathy, malnutrition, liver and kidney dysfunction, and so forth. A recent publication from the PHTS examined outcomes of 1115 children with underlying congenital heart disease who were listed for heart transplantation, including 262 following Glenn, 269 following Fontan, and 584 with other forms of congenital heart disease. Survival following heart transplantation in those 3 groups was comparable, suggesting that Fontan patients do not fare worse. ${ }^{33}$ Similarly, several experienced centers have recently shown that a prior Fontan operation was not associated with inferior outcomes. ${ }^{9,14}$ Although it was not possible to assess the progression of protein losing enteropathy following transplantation in the current series, previous reports have shown that patients who had protein losing enteropathy usually recovered within 6 months after heart transplantation. ${ }^{14}$

Interestingly, the UNOS listing status, age, and the presence of PRAs higher than $10 \%$ did not significantly affect survival following heart transplantation. These improved results in children with high PRAs may be attributed to several advances in pretransplant evaluation of allosensitization, treatment of sensitized patients, induction and maintenance immunosuppression, and surveillance and treatment of rejection following heart transplantation. ${ }^{34-36}$

We identified that donor cause of death other than anoxic brain injury and African American race were both risk factors for mortality following heart transplantation. This association between the donor cause of death and survival after transplantation is interesting, as a recent larger report from PHTS showed that survival following heart transplantation in children was not affected by the cause of donor death. ${ }^{37}$ It is unlikely that there is a special connection between the cause of death and survival following transplantation in patients who had a prior Norwood operation and our finding might be anecdotal due to the relatively smaller patient cohort. On the other hand, the divergence in survival between races in our study was remarkable and comparable to other reports that have shown worse outcomes in African American heart transplant recipients. ${ }^{38-40}$ These differences can be attributed to differences in socioeconomic conditions and health literacy, in addition to higher degree of sensitization and human leukocyte antigen mismatch.

\section{Study Limitations}

This study should be interpreted within the context of its limitations. This retrospective multi-institutional registry series is subject to inherent problems with selection bias related to indications to listing and transplantation and institutional variations in the management of patients listed for transplantation or after heart transplantation. Given the changes in definitions and in the data collection forms over time, some of the variables had missing data. In addition, the completeness of some of the data, such as the list of all previous cardiac surgeries, the cause of death prior to or after transplantation could not be verified. And finally, despite being by far the largest series of children with prior Norwood operation who were listed to receive heart transplantation, the analysis might have been limited by the sample size, the multiple variables that could affect outcome, the presence of missing data, and the presence of unmeasured covariables such as center variation.

\section{Summary}

Heart transplantation is a valid strategy to salvage children with single ventricle who have undergone a Norwood operation and failed to progress at different palliation stages. Long-term results are encouraging and comparable to published reports on heart transplantation in children with other forms of congenital heart disease. Nonetheless, waiting list mortality is high and is more elevated in younger children who are listed soon after Norwood and those with worse clinical condition. Efforts to better stabilize those patients and to increase the donor pool could help decreasing this waiting list mortality. In 
patients who received heart transplantation, survival was not affected by last palliation stage or by the presence of elevated PRAs, reflecting advances in the current management strategies of sensitized patients undergoing heart transplantation.

\section{Conflict of Interest Statement}

Authors have nothing to disclose with regard to commercial support.

\section{References}

1. Alsoufi B, Bennetts J, Verma S, Caldarone CA. New developments in the treatment of hypoplastic left heart syndrome. Pediatrics. 2007;119:109-17.

2. Feinstein JA, Benson DW, Dubin AM, Cohen MS, Maxey DM, Mahle WT, et al. Hypoplastic left heart syndrome: current considerations and expectations. J Am Coll Cardiol. 2012;59:S1-42.

3. Tweddell JS, Sleeper LA, Ohye RG, Williams IA, Mahony L, Pizarro C, et al. Intermediate-term mortality and cardiac transplantation in infants with single-ventricle lesions: risk factors and their interaction with shunt type. $J$ Thorac Cardiovasc Surg. 2012;144:152-9.

4. Murtuza B, Dedieu N, Vazquez A, Fenton M, Burch M, Hsia TY, et al. Results of orthotopic heart transplantation for failed palliation of hypoplastic left heart. Eur J Cardiothorac Surg. 2013;43:597-603.

5. Everitt MD, Boyle GJ, Schechtman KB, Zheng J, Bullock EA, Kaza AK, et al. Early survival after heart transplant in young infants is lowest after failed single-ventricle palliation: a multi-institutional study. J Heart Lung Transplant. 2012;31:509-16.

6. Alsoufi B, Deshpande S, McCracken C, Kogon B, Vincent R, Mahle W, et al. Results of heart transplantation following failed staged palliation of hypoplastic left heart syndrome and related single ventricle anomalies. Eur J Cardiothorac Surg. 2015;48:792-9.

7. Chrisant MR, Naftel DC, Drummond-Webb J, Chinnock R, Canter CE, Boucek MM, et al. Fate of infants with hypoplastic left heart syndrome listed for cardiac transplantation: a multicenter study. J Heart Lung Transplant. 2005;24:576-82.

8. Jacobs JP, Asante-Korang A, O'Brien SM, Chai PJ, Dadlani GH, Rodriguez-Fazzi GL, et al. Lessons learned from 119 consecutive cardiac transplants for pediatric and congenital heart disease. Ann Thorac Surg. 2011;91:1248-54.

9. Alsoufi B, Deshpande S, McCracken C, Kogon B, Vincent R, Mahle W, et al. Outcomes and risk factors for heart transplantation in children with congenital heart disease. J Thorac Cardiovasc Surg. 2015;150:1455-62.e3.

10. Newburger JW, Sleeper LA, Frommelt PC, Pearson GD, Mahle WT, Chen S, et al. Transplantation-free survival and interventions at 3 years in the single ventricle reconstruction trial. Circulation. 2014;129:2013-20.

11. Nathan M, Sleeper LA, Ohye RG, Frommelt PC, Caldarone CA, Tweddell JS, et al. Technical performance score is associated with outcomes after the Norwood procedure. J Thorac Cardiovasc Surg. 2014;148:2208-13.

12. Voeller RK, Epstein DJ, Guthrie TJ, Gandhi SK, Canter CE, Huddleston CB. Trends in the indications and survival in pediatric heart transplants: a 24-year single-center experience in 307 patients. Ann Thorac Surg. 2012;94:807-15.

13. Davies RR, Sorabella RA, Yang J, Mosca RS, Chen JM, Quaegebeur JM. Outcomes after transplantation for "failed" Fontan: a single-institution experience. J Thorac Cardiovasc Surg. 2012;143:1183-92.

14. Kanter KR, Mahle WT, Vincent RN, Berg AM, Kogon BE, Kirshbom PM. Heart transplantation in children with a Fontan procedure. Ann Thorac Surg. 2011;91: 823-30.

15. Griffiths ER, Kaza AK, Wyler von Ballmoos MC, Loyola H, Valente AM, Blume ED, et al. Evaluating failing Fontans for heart transplantation: predictors of death. Ann Thorac Surg. 2009;88:558-64.

16. Bernstein D, Naftel D, Chin LJ, Addonizio LJ, Gamberg P, Blume ED, et al. Outcome of listing for cardiac transplantation for failed Fontan: a multi-institutional study. Circulation. 2006;114:273-80.

17. Marx GR, Shirali G, Levine JC, Guey LT, Cnota JF, Baffa JM, et al. Multicenter study comparing shunt type in the Norwood procedure for single-ventricle lesions: three-dimensional echocardiographic analysis. Circ Cardiovasc Imaging. 2013;6:934-42.
18. Almond CS, Thiagarajan RR, Piercey GE, Gauvreau K, Blume ED, Bastardi HJ, et al. Waiting list mortality among children listed for heart transplantation in the United States. Circulation. 2009;119:717-27.

19. Dipchand AI, Kirk R, Mahle WT, Tresler MA, Naftel DC, Pahl E, et al. Ten yr of pediatric heart transplantation: a report from the Pediatric Heart Transplant Study. Pediatr Transplant. 2013;17:99-111.

20. Henderson HT, Canter CE, Mahle WT, Dipchand AI, LaPorte K, Schechtman KB, et al. ABO-incompatible heart transplantation: analysis of the Pediatric Heart Transplant Study (PHTS) database. J Heart Lung Transplant. 2012:31:173-9.

21. Dipchand AI, Pollock Barziv SM, Manlhiot C, West LJ, Vandervliet M, McCrindle BW. Equivalent outcomes for pediatric heart transplantation recipients: $\mathrm{ABO}$-blood group incompatible versus $\mathrm{ABO}$-compatible. Am J Transplant. 2010;10:389-97.

22. Gajarski RJ, Mosca RS, Ohye RG, Bove EL, Crowley DC, Custer JR, et al. Use of extracorporeal life support as a bridge to pediatric cardiac transplantation. $J$ Heart Lung Transplant. 2003;22:28-34.

23. Almond CS, Singh TP, Gauvreau K, Piercey GE, Fynn-Thompson F, Rycus PT, et al. Extracorporeal membrane oxygenation for bridge to heart transplantation among children in the United States: analysis of data from the Organ Procurement and Transplant Network and Extracorporeal Life Support Organization Registry. Circulation. 2011;123:2975-84.

24. Del Nido PJ, Armitage JM, Ficker FJ, Shaver M, Cipriani L, Dayal G, et al. Extracorporeal membrane oxygenation support as a bridge to pediatric heart transplantation. Circulation. 1994;90:II-66-9.

25. Blume ED, Naftel DC, Bastardi HJ, Duncan BW, Kirklin JK, Webber SA. Outcomes of children bridged to heart transplantation with ventricular assist devices: a multi-institutional study. Circulation. 2006; 113:2313-9.

26. Eghtesady P, Almond CS, Tjossem C, Epstein D, Imamura M, Turrentine M, et al. Post-transplant outcomes of children bridged to transplant with the Berlin Heart EXCOR Pediatric ventricular assist device. Circulation. 2013; 128:S24-31.

27. Morales DL, Zafar F, Rossano JW, Salazar JD, Jefferies JL, Graves DE, et al. Use of ventricular assist devices in children across the United States: analysis of 7.5 million pediatric hospitalizations. Ann Thorac Surg. 2010;90: 1313-8.

28. Hetzer R, Potapov EV, Alexi-Meskishvili V, Weng Y, Miera O, Berger F, et al. Single-center experience with treatment of cardiogenic shock in children by pediatric ventricular assist devices. J Thorac Cardiovasc Surg. 2011;141: 616-23.

29. Fraser CD Jr, Jaquiss RD, Rosenthal DN, Humpl T, Canter CE, Blackstone EH, et al. Prospective trial of a pediatric ventricular assist device. N Engl J Med. 2012; 367:532-41.

30. Dipchand AI, Kirk R, Edwards LB, Kucheryavaya AY, Benden C, Christie JD, et al. The Registry of the International Society for Heart and Lung Transplantation: Sixteenth Official Pediatric Heart Transplantation Report-2013; focus theme: age. Heart Lung Transplant. 2013;32: 979-88.

31. Kirk R, Dipchand AI, Edwards LB, Kucheryavaya AY, Benden C, Christie JD, et al. The Registry of the International Society for Heart and Lung Transplantation: Fifteenth Pediatric Heart Transplantation Report-2012. J Heart Lung Transplant. 2012;31:1065-72.

32. Alsoufi B, Kanter K, McCracken C, Kogon B, Vincent R, Mahle W, et al. Outcomes and risk factors for heart transplantation in children with end stage cardiomyopathy. Eur J Cardiothorac Surg. February 26, 2015 [Epub ahead of print].

33. Kovach JR, Naftel DC, Pearce FB, Tresler MA, Edens RE, Shuhaiber JH, et al. Comparison of risk factors and outcomes for pediatric patients listed for heart transplantation after bidirectional Glenn and after Fontan: an analysis of the Pediatric Heart Transplant Study. J Heart Lung Transplant. 2012; 3:133-9.

34. Everitt MD, Pahl E, Schechtman KB, Zheng J, Ringewald JM, L'ecuyer T, et al. Rejection with hemodynamic compromise in the current era of pediatric heart transplantation: a multi-institutional study. J Heart Lung Transplant. 2011;30: 282-8.

35. Mahle WT, Tresler MA, Edens RE, Rusconi P, George JF, Naftel DC, et al. Allosensitization and outcomes in pediatric heart transplantation. J Heart Lung Transplant. 2011;30:1221-7.

36. Castleberry C, Ryan TD, Chin C. Transplantation in the highly sensitized pediatric patient. Circulation. 2014;129:2313-9. 
37. Conway J, Chin C, Kemna M, Burch M, Barnes A, Tresler M, et al. Donors' characteristics and impact on outcomes in pediatric heart transplant recipients. Pediatr Transplant. 2013;17:774-81.

38. Mahle WT, Kanter KR, Vincent RN. Disparities in outcome for black patients after pediatric heart transplantation. J Pediatr. 2005;147:739-43.

39. Beatty PG, Mori M, Milford E. Impact of racial genetic polymorphism on the probability of finding an HLA-matched donor. Transplantation. 1995;60:778-83.
40. Kanter KR, Berg AM, Mahle WT, Vincent RN, Kilgo PD, Kogon BE, et al Donor-recipient race mismatch and graft survival after pediatric heart transplantation. Ann Thorac Surg. 2009;87:204-9.

Key Words: heart transplantation, hypoplastic left heart syndrome, Norwood operation

Readers who found these articles interesting may also like to read the following papers found in recent and future issues of our sister publications, Seminars in Thoracic and Cardiovascular Surgery and Operative Techniques in Thoracic and Cardiovascular Surgery!

\section{Congenital Heart Disease}

State of the Art: Interrupted Aortic Arch. Richard Jonas. Semin Thorac Cardiovasc Surg 2015; Summer; 27(2):177-188.

Original Submission: Should Tricuspid annuloplasty be performed with pulmonary valve replacement for pulmonary regurgitation in repaired tetralogy of fallot? Pranava Sinha. Semin Thorac Cardiovasc Surg 2015; Summer; 27(2): 159-165.

Editorial Commentary: PI Leads to RVE, Which Leads to TR, Which Leads to More RVE, Which Leads to More TR: A Vicious Cycle? Charles B. Huddleston. Semin Thorac Cardiovasc Surg 2015; Summer; 27(2): 166-167.

Original Submission: Unsatisfactory early and late outcomes after Fontan surgery delayed to adolescence and adulthood. Yves D’Udekem. Semin Thorac Cardiovasc Surg 2015; Summer; 27(2):168-174.

Editorial Commentary: The Fontan Operation: Is Timing Everything? Harold M Burkhart. Semin Thorac Cardiovasc Surg 2015; Summer; 27(2): 175.

Discussions in Cardiothoracic Treatment and Care: Tetralogy of Fallot. Charles Fraser. Semin Thorac Cardiovasc Surg 2015; Summer; 27(2):189-204.

Current Readings: Pulmonary Valve Replacement for Pulmonary Valve Insufficiency in Formerly Repaired Tetralogy of Fallot. Brian Kogon. Semin Thorac Cardiovasc Surg 2015; Spring; 27(1):57-64.

Original Submission: Preliminary experience in the use of an extracellular matrix (CorMatrix) as a tube graft: Word of caution. Narutoshi Hibino. Expected Publication December 2015.

Original Submission: Relationship of normal aortic valve cusp dimensions: a tool to optimize cusp reconstruction valvuloplasty. Sujata Subramanian. Expected Publication December 2015.

Original Submission: Outcomes of truncus arteriosus repair in children: 35 years of experience from a single institution. Igor Konstantinov. Expected Publication December 2015.

Original Submission: Efficacy of artificial chordal reconstruction for idiopathic severe mittral regurgitation due to chordal rupture in infancy. Sadahiro Sai. Expected Publication December 2015.

Original Submission: The mid-term outcomes of bioprosthetic pulmonary valve replacement in children. Takeshi Shinkawa. Expected Publication December 2015.

Original Submission: Health-related quality of life in adult survivors after the Fontan operation. James Kirklin. Expected Publication December 2015.

Repair of Atrioventricular Septal Defects: The 2-Patch Sandwich Technique. Hagi Dekel. Oper Tech Thorac Cardiovasc Surg 2015; Spring; 20(1):63-74.

Classic Single-Patch Repair of Atrioventricular Septal Defects. Anees J. Razzouk. Oper Tech Thorac Cardiovasc Surg 2015; Spring; 20(1):75-86.

Melody Valve for Mitral Valve Replacement. Sitaram M. Emani. Oper Tech Thorac Cardiovasc Surg 2014; Winter; 19(4):454-463. Single-Stage Neonatal Repair of Taussig-Bing Anomaly. Bahaaldin Alsoufi. Oper Tech Thorac Cardiovasc 2014; Winter; 19(4): 464-481

Repair of Anomalous Coronary Artery from the Pulmonary Artery by Aortic Implantation. Anthony Azakie. Expected Publication December 2015. 
TABLE E1. Comparison of selected patients' characteristics and heart transplantation details between the 2 study eras

\begin{tabular}{|c|c|c|c|}
\hline Variable & $\begin{array}{c}\text { Era 1 } \\
(1993-2002), \\
\mathbf{n}=112 \\
\end{array}$ & $\begin{array}{c}\text { Era } 2 \\
(2003-2012) \\
\mathbf{n}=141 \\
\end{array}$ & $\begin{array}{c}P \\
\text { value }\end{array}$ \\
\hline Status at listing, $\mathrm{n}(\%)$ & & & .001 \\
\hline UNOS 1 & $72(64)$ & $116(82)$ & \\
\hline UNOS 2 & $40(36)$ & $25(18)$ & \\
\hline Stage, n $(\%)$ & & & .22 \\
\hline Norwood & $46(41)$ & $43(31)$ & \\
\hline Glenn & $39(35)$ & $57(40)$ & \\
\hline Fontan & $27(24)$ & $41(29)$ & \\
\hline ECMO at listing, $\mathrm{n}(\%)$ & $16(14)$ & $15(11)$ & .44 \\
\hline $\begin{array}{l}\text { Other mechanical circulatory } \\
\text { support at listing, } \mathrm{n}(\%)\end{array}$ & $2(2)$ & $0(0)$ & .20 \\
\hline ECMO at transplantation, $\mathrm{n}(\%)$ & $10(9)$ & $6(4)$ & .19 \\
\hline $\begin{array}{l}\text { Other mechanical circulatory } \\
\text { support at transplantation, } \mathrm{n}(\%)\end{array}$ & $0(0)$ & $2(1)$ & .50 \\
\hline Age at listing, y, median (IQR) & $1.4(0.4-3.2)$ & $1.6(0.4-4.9)$ & .02 \\
\hline $\begin{array}{l}\text { Duration on waitlist, } d, \\
\text { median (IQR) }\end{array}$ & $37(13-87)$ & $65(26-155)$ & .07 \\
\hline
\end{tabular}

TABLE E2. The cause of death following listing for transplantation and following heart transplantation

\begin{tabular}{|c|c|c|}
\hline Cause of death & No. of patients & Percentage \\
\hline Patient died & 253 & $114(45 \%)$ \\
\hline Primary cause of death & 114 & \\
\hline Accidental & & $1(1 \%)$ \\
\hline Coronary artery disease & & $18(16 \%)$ \\
\hline Fatal arrhythmia & & $8(7 \%)$ \\
\hline Infection & & $13(11 \%)$ \\
\hline Lymphoma & & $2(2 \%)$ \\
\hline Postoperative hemorrhage & & $2(2 \%)$ \\
\hline $\begin{array}{l}\text { Pulmonary hypertension/right } \\
\text { ventricular failure }\end{array}$ & & $2(2 \%)$ \\
\hline Acute rejection & & $4(4 \%)$ \\
\hline Respiratory failure & & $11(10 \%)$ \\
\hline Sudden cardiac death & & $11(10 \%)$ \\
\hline Other & & $41(36 \%)$ \\
\hline Unknown & & $1(1 \%)$ \\
\hline $\begin{array}{l}\text { Primary cause of death of patients } \\
\text { without transplant }\end{array}$ & 58 & \\
\hline Coronary artery disease & & $15(26 \%)$ \\
\hline Fatal arrhythmia & & $6(10 \%)$ \\
\hline Infection & & $3(5 \%)$ \\
\hline Respiratory failure & & $8(14 \%)$ \\
\hline Sudden cardiac death & & $8(14 \%)$ \\
\hline Other & & $17(29 \%)$ \\
\hline Unknown & & $1(2 \%)$ \\
\hline $\begin{array}{l}\text { Primary cause of death of patients } \\
\text { who died after transplant }\end{array}$ & 56 & \\
\hline Accidental & & $1(2 \%)$ \\
\hline Coronary artery disease & & $3(5 \%)$ \\
\hline Fatal arrhythmia & & $2(4 \%)$ \\
\hline Infection & & $10(18 \%)$ \\
\hline Lymphoma & & $2(4 \%)$ \\
\hline Postoperative hemorrhage & & $2(4 \%)$ \\
\hline $\begin{array}{l}\text { Pulmonary hypertension/right } \\
\text { ventricular failure }\end{array}$ & & $2(4 \%)$ \\
\hline Acute rejection & & $4(7 \%)$ \\
\hline Respiratory failure & & $3(5 \%)$ \\
\hline Sudden cardiac death & & $3(5 \%)$ \\
\hline Other & & $24(42 \%)$ \\
\hline
\end{tabular}


TABLE E3. Patients and surgical characteristics that were included in our analysis models following listing and following heart transplantation

Factors included in both survival following listing and following transplantation models:

Gender

Weight at listing

Race

Age at listing

Physiologic state at listing (Norwood, Glenn, Fontan)

Era at listing

Listing UNOS status

Protein losing enteropathy

Renal failure

Mechanical support

Cytomegalovirus status

Epstein-Barr virus status

Panel reactive antibodies (B and T)

Listed for prospective crossmatch

Listing for ABO-incompatible heart

Hemodynamics closest to listing (including mean pulmonary artery pressure)

Factors included in survival following transplantation model:

Age at transplantation

Weight at transplantation

Era at transplantation

UNOS status at transplantation

Mechanical support at transplantation

Donor-specific crossmatch

ABO-incompatible heart

Cardiopulmonary bypass duration

Donor cold ischemic time duration

Atrial anastomosis technique (atrial vs bicaval)

Mechanical support following transplantation

Donor age

Donor weight

Donor/recipient weight ratio

Donor cause of death

Donor positive cytomegalovirus in a negative recipient

Donor positive Epstein-Barr virus in a negative recipient

UNOS, United Network for Organ Sharing.
TABLE E4. Factors associated with hazard of mortality after listing before transplantation

\begin{tabular}{|c|c|c|c|c|c|}
\hline Univariable risk factors & $\%$ & HR & UCL & LCL & $P$ value \\
\hline Mechanical circulatory support at listing & & 5.29 & 2.65 & 10.56 & $<.001$ \\
\hline $\begin{array}{l}\text { Higher mean pulmonary artery pressure } \\
\text { at listing (per I } \mathrm{mm} \mathrm{Hg} \text { ) }\end{array}$ & & 1.08 & 1.04 & 1.12 & $<.001$ \\
\hline UNOS status 1 at listing & & 4.26 & 1.99 & 9.10 & $<.001$ \\
\hline Listing after Norwood & & 2.59 & 1.52 & 4.40 & .001 \\
\hline Younger age at listing (per year) & & 1.15 & 1.04 & 1.27 & .004 \\
\hline Lower weight at listing (per kg) & & 1.05 & 1.01 & 1.10 & .01 \\
\hline Renal failure at listing & & 2.95 & 1.17 & 7.43 & .02 \\
\hline \multicolumn{6}{|l|}{ Multivariable risk factors* } \\
\hline $\begin{array}{l}\text { Mechanical circulatory support } \\
\text { at listing }\end{array}$ & 92 & 4.13 & 2.04 & 8.34 & $<.001$ \\
\hline $\begin{array}{l}\text { Higher mean pulmonary artery } \\
\text { pressure } \\
\text { at listing (per } \mathrm{I} \mathrm{mm} \mathrm{Hg} \text { ) }\end{array}$ & 83 & 1.07 & 1.03 & 1.10 & $<.001$ \\
\hline UNOS status 1 at listing & 78 & 3.44 & 1.58 & 7.49 & .002 \\
\hline
\end{tabular}

TABLE E5. Factors associated with hazard of mortality after heart transplantation

\begin{tabular}{|c|c|c|c|c|c|}
\hline Univariable risk factors & $\%$ & HR & UCL & LCL & $\boldsymbol{P}$ \\
\hline Nonwhite race & & 2.38 & 1.32 & 4.35 & .004 \\
\hline $\begin{array}{l}\text { Mechanical circulatory support after } \\
\text { transplant }\end{array}$ & & 2.89 & 1.14 & 7.34 & .03 \\
\hline Donor cause of death other than anoxia & & 2.44 & 1.11 & 5.56 & .03 \\
\hline \multicolumn{6}{|l|}{ Multivariable risk factors* } \\
\hline Nonwhite race & 73 & 2.18 & 1.19 & 3.99 & .01 \\
\hline Donor cause of death other than anoxia & 65 & 2.23 & 1.00 & 5.01 & .05 \\
\hline
\end{tabular}

